\title{
COMPARISON TWO LOCATIONS OF LIGHTNING DETECTION
}

\author{
Deni Septiadi*1, Hadi Suntoko ${ }^{2}$, Anton Widodo ${ }^{3}$, Riza Arian Noor ${ }^{4}$ \\ ${ }^{1}$ School of Meteorology Climatology and Geophysics (STMKG), South-Tangerang, Indonesia \\ ${ }^{2}$ National Nuclear Energy Agency of Indonesia (BATAN), Jakarta, Indonesia \\ ${ }^{3}$ Master program of Indonesia University (UI), Depok, Jawa Barat, Indonesia \\ ${ }^{4}$ Syamsudin Noor Meteorological Station, Banjarmasin, Indonesia \\ *Email:deni.septiadi@bmkg.go.id,zeptiadi@yahoo.co.id
}

\begin{abstract}
The objective of this study was to identify the lightning distribution by comparing of two lightning sensors located in Jakarta and Bandung. Using Storm Tracker Lightning Detector maintained by the Indonesia Agency for Meteorology, Climatology and Geophysics (BMKG), Cloud-to-Ground lightning (CG) analyzed with a various radius i.e. $0.1^{\circ}, 0.5^{\circ}$ and $1.0^{\circ}$. Storm Tracker Lightning Detector consists of an antenna connected to the PCI card and able to detect Low Frequency (LF) of radio signals generated by lightning (10 $\mathrm{KHz}$ to $200 \mathrm{KHz}$ ). The data used are based on the available records of near real time 15 minutes CG lightning data. This study aims at revealing ideally possible location of the lightning sensor to optimize lightning detection. For further analysis, the distribution of the CG lightning estimated in the target area located about the middle between Jakarta and Bandung. The analysis of lightning described by calculating the detection efficiency of lightning sensor and the analysis of lightning location error.
\end{abstract}

Keywords : magnetic direction finding; cloud-to-ground lightning; detection efficiency.

\section{INTRODUCTION}

Recently, lightning has come into the focus of scientific interest as well as shown on volcanic eruptions (Behnke et. al., 2012), extremely intense forest fires (Kochtubajda et. al., 2006), the heaviest precipitation and also some techniques and relevant studies for directly estimating rainfall from lightning observations (Michaelides et. al., 2009; Piepgrass et. al., 1982; Soula and Chauzy, 2001; Soula et. al., 1998; Septiadi et. al., 2016; Septiadi and Safwan, 2011; Septiadi et. al., 2011; Septiadi and Bayong, 2011; Septiadi et. al., 2010).

Lightning is a transient electrical discharge with a typical path length of hundreds of metres to kilometres which is occurring due to loss of electrical charge contained in the cloud, either positive or negative. Furthermore, as mentioned by Mather and Harrison (2006) and Price (2008), lightning discharges may commonly be within a cloud (Intra Cloud, IC), among cloudto-cloud (Inter Cloud, CC) or from cloud to the ground (Cloud-to-Ground, CG). The CG lightning produces strong emission in the near surface on the radio waves of Low Frequency (LF) while the IC emits a radio wave signal from High Frequency (HF) to Very High Frequency (VHF) from the cloud as mentioned by Proctor (1991); Suszcynsky et. al. (2000); Thomas et. al. (2000).

According to Finke and Kreyer (2002); Uman (2003), lightning is formed in a successive phase with the initial process is within the cloud with enough of electric field and the process is almost visible discharge moves toward to the earth. Lightning can be detected from the surface and space by using an optical sensor. The electric radio waves or magnetic waves generated by the electric discharge within a certain frequency, such as the Low Frequency (LF, 30-300 KHz), Very Low frequency (VLF, 3-30 KHz), Extremely Low Frequency (ELF, 30-300 Hz), and Very High Frequency (VHF, 30-300 MHz) as mentioned by MacGorman and Rust (1998); Schumann and Huntrieser (2007). 
Furthermore, the electrical charge released during a lightning event will produce very strong emissions across various spectrum channels, such as low frequency (LF) due to cloud to ground lightning (CG), as well as high frequency spectrum (VHF) due to lightning that occurs in the cloud (IC). Emissions in the form of electromagnetic waves will be detected by lightning instruments. Strong or weak lightning signal received by the instrument will affect the calculation of the distance and the location of lightning. Hence, there are several sources of error in lightning measurements: instrument calibration, lightning distance determination, and lightning location determination Cummins et. al. (2008); Demetriades et. al. (2010); Holleman et. al. (2006).

As mentioned by Cummins et. al. (2008), many researchers agree (Demetriades and Holle, 2005; Johnson et. al., 1982; Squires and Businger, 2008), that lightning detection has a great value for realtime storm tracking, warning, and nowcasting. Unfortunately, until this moment in Indonesia, research of lightning is very limited, particularly lightning research based on near real time data by using a storm tracker lightning detector. Therefore, this paper tries to analyze CG lightning using a groundbased Storm Tracker lightning detector that is employing a Magnetic Direction Finding (MDF). Hence, by considering the accuracy and efficiency of the system, observation in this study is limited to the CG lightning. This study will be focused on the utilization of the $\mathrm{CG}$ lightning data following validation techniques. Furthermore, this paper also objectively tries to identify how the performance of a lightning detection system by examining either spatially or temporally the distributions of two lightning detection located in Jakarta and Bandung (see Fig. 1).

\section{MATERIAL AND METHOD}

\section{A. Data collection and sensor performance}

The study area is located in Jakarta $\left(6^{\circ} 12^{\prime}\right.$ $36.47^{\prime \prime} \mathrm{S}$ and $\left.106^{\circ} 50^{\prime} 38.04^{\prime \prime} \mathrm{E}\right)$ and Bandung $\left(6^{\circ} 54^{\prime} 51.90^{\prime \prime} \mathrm{S}\right.$ and $\left.107^{\circ} 36^{\prime} 33.50^{\prime \prime} \mathrm{E}\right)$ of Indonesia. Near real time (15 minutes) CG lightning data during January 2009 provided by the Indonesia Agency for Meteorology, Climatology and Geophysics (BMKG). All data then accumulated into daily data. Thus, during January 2009 obtained 31 samples $(n=31)$ of lightning data. Two lightning sensors in Jakarta and Bandung compared and analyzed at the target area located on $6^{\circ} 33^{\prime} 21.89^{\prime \prime} \mathrm{S}$ and $107^{\circ} 13^{\prime} 13.61 \mathrm{E}$ with a distance $\pm 60 \mathrm{~km}$ from Jakarta or Bandung (see Fig. 1). Lightning detected by using ground-based Storm Tracker Lightning Detector (LD) that is employing a Magnetic Direction Finding (MDF) and consists of loop antenna were connected with PCI card and installed with a personal computer. LD is a single station sensor that can detect the direction and distance of lightning. Nevertheless, the LD sensor is included in the lightning instruments used by WMO members as the result of a survey evaluation by Dahoui (2010).

LD itself has been used in more than 36 countries, including America, Australia, Netherlands, Germany, Japan, England, Spain and Indonesia. The lightning observation system built and developed by BOLTEK consists of an antenna and connected to a PCI card installed with a computer, detects LF signals $(10 \mathrm{KHz}$ to $200 \mathrm{KHz})$ and uses Direction Finding (DF) antenna to determine direction of lightning.

As mentioned by Kochtubajda et. al. (2006) and Kochtubajda et. al. (2002), lightning analysis still resulting the uncertainties in the location accuracy and the detection efficiency of the network. Expected error range is 3-10 $\mathrm{km}$ within the high density region of the network and $12-22 \mathrm{~km}$ at its periphery, with an overall detection efficiency of about $70 \%$. Electric discharge is released when the lightning and cause very strong emissions in various spectral bands from both LF due to CG lightning and the VHF due to IC lightning. Emissions in the form of electromagnetic waves will be detected by the lightning sensor (Finke and Kreyer, 2002). Strong or weak lightning signals received sensors will affect the distance calculation and determination of the location of lightning. Currently, lightning instruments, whether in the single stations or multi stations, can not be calibrated yet. The World Meteorological Organization (WMO) as a world capable organization does not yet have an instrument standard for lightning measurements. Thus, each lightning instrument has its own specificity, especially in measuring the number of strikes. The calibration applied is only limited to factory calibrations which of course will be different for each manufacturer. 
Some lightning manufacturers like VAISALA Inc. just make comparisons with other observation measurements such as cloud cover to test instrument reliability as demonstrated by Cramer and Cummins, 1999; Demetriades and Holle, 2005; Holleman et. al., 2006.

The detection efficiency of Storm Tracker lightning detector has been estimated by the number of measurements in the event of a storm, where the efficiency of each parameter for CG and IC lightning is $85 \% \pm 6 \%$ and $20 \%$ $\pm 6 \%$ (Tinmaker and Ali, 2010). The distance between the source of lightning and the instrument becomes important to know. A very possible mistake is the inability of the instrument to capture the lightning signal properly and correctly. This error may be caused by disturbances around the space through which lightning electromagnetic waves or disturbances around the instrument arise from the inappropriate placement of electronic equipment. Thus, the measured distance observed through the instrument is not an actual distance.

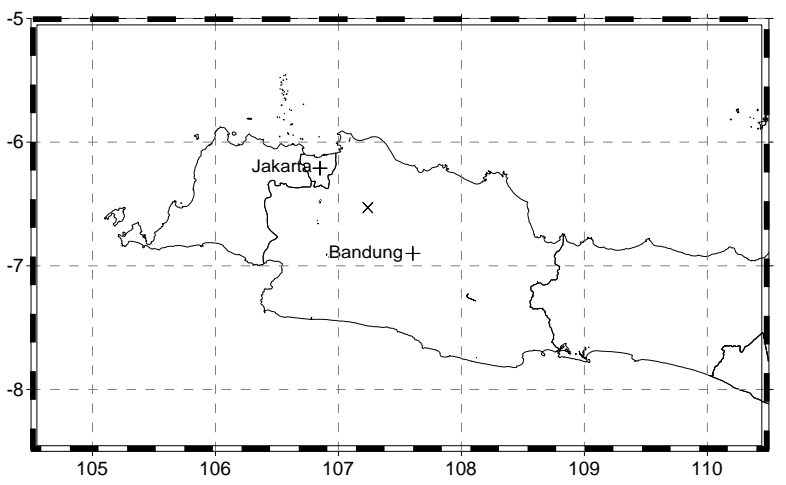

Fig. 1 LD Sensor of Jakarta and Bandung labeled as "+", meanwhile target area labeled as " $x$ ".

\section{B. Single station lightning measurement}

Lightning measurements using a single station generally combines the Direction Finding (DF) method with the lightning source distance estimation technique of the instrument. The estimation of the lightning distance is performed using the ratio between the magnetic field $(H)$ and the electric field $(E)$ generated by the lightning strike. To estimate accurately the distance and position of the lightning, a single DF-based lightning measuring instrument uses an orthogonal magnetic antenna loop. An orthogonal and vertical antenna loop is used for the comparison or ratio of lightning electromagnetic signals in determining the angle of lightning strikes (Ibrahim and Ghazali, 2013). The single station instrument working with a magnetic loop antenna North-South and East-West as well as coaxial cable to estimate the distance of lightning i.e the comparison between magnetic field $(H)$ and electric field $(E)$ :

Distance $=\frac{\sqrt{H_{\omega}}}{E_{\omega}}$

With $H_{\omega}$ is a horizontal magnetic field and $E_{\omega}$ is a vertical electric field. Since each magnetic antenna loop produces an angular $(\theta), V_{m}$ dependent electric voltage between the loop plane and the signal source, the loop area $(F)$ and the number of loops $(n)$ then the electrical voltage formulation is calculated by using:

$V_{m}=\mu . H . \omega \cdot F \cdot n \cdot \cos \theta$

Meanwhile, lightning direction can be calculated using North-South $\left(H_{n s}\right)$ magnetic field comparisons and East-West $\left(H_{e w}\right)$ magnetic fields:

Direction $=\tan ^{-1} \frac{H_{n s}}{H_{e w}}$

\section{Statistics and filtering at a radius of $0.1^{\circ}$;} $0.5^{\circ}$ and $1.0^{\circ}$

Strong or weak correlations between lightning phenomena at two sensors location in the target area analyzed by using Pearson Product Moment $(r)$ correlation as follows:

$$
r_{x y}=\frac{n \sum X Y-\left(\sum X\right)\left(\sum Y\right)}{\sqrt{\left\{n \sum X^{2}-\left(\sum X\right)^{2}\right\}\left\{n \sum Y^{2}-\left(\sum Y\right)^{2}\right\}}}
$$

Pearson Product Moment Correlation is denoted as $r$ with the provision that the value of $r$ is $-1<r<+1$ ). Suppose the value of $r=-1$ means that the correlation is perfectly negative; $r=0$ means there is no correlation and $r=1$ means the correlation is very strong. In detail, these values are shown in the following table:

TABLE 1. COEFICIENT CORRELATION $R$ [34]

\begin{tabular}{|c|c|}
\hline Interval & Description \\
\hline $0,80-1,00$ & Very strong \\
$0,60-0,80$ & Strong \\
$0,40-0.60$ & Medium \\
$0,20-0,40$ & Weak \\
$0,00-0,20$ & Very weak \\
\hline
\end{tabular}


Meanwhile, Standar Deviation $(\sigma)$ done to identify and analyze the dispersion of $\mathrm{CG}$ lightning data. The Standard Deviation is the positive square root of the variance. It has the advantage of being in the same units as the attribute (Olea, 2008).

$\sigma=\sqrt{\frac{\sum_{i=1}^{n}\left(x_{i}-\mu\right)^{2}}{n}}$

where :

$\mu=$ the mean of data set

$n=$ number of elements in data set

$\mathrm{X}_{\mathrm{i}}=$ the $i^{\text {th }}$ element of the data set

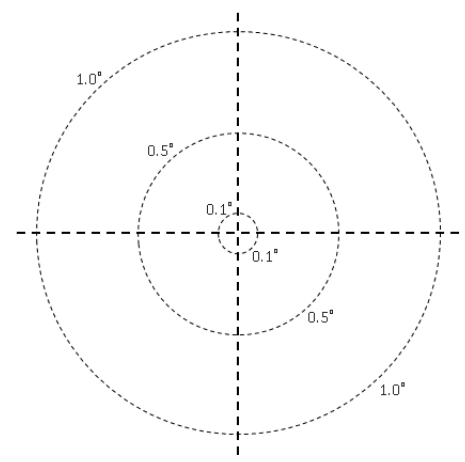

Fig. 2 Detection radius of lightning by LD.

By default for the filtering analysis, the LD lightning sensor can detect lightning up to a radius of about $540 \mathrm{~km} \mathrm{(} 300$ miles). However, it is necessary to re-examine the sensor detection efficiency to see the reliability of the instrument. Detection efficiency analysis is useful in designing and building the basis of lightning network design in Indonesia. Therefore, in this study the LD detection radius was made into three of radius i.e. $0.1^{\circ} ; 0.5^{\circ}$ and $1.0^{\circ}$ as in Fig. 2.

\section{RESULTS AND DISCUSSION}

\section{A. Detection efficiency of lightning sensor}

To see the distribution of each sensor (Jakarta and Bandung), it is necessary to analyze the distribution on the target area (labeled as " $\mathrm{x}$ " in Fig. 1). The distance of the target area is about $60 \mathrm{~km}$ in the middle between Jakarta and Bandung. The location of the target area is taken with the consideration that the distance between of two sensors is $120 \mathrm{~km}$. Furthermore, the plot of lightning distribution is filtered within a radius of $0.1^{\circ}, 0.5^{\circ}$ and $1.0^{\circ}$.
The number of samples data selected for calculation is $31(\mathrm{n}=31)$ representing daily data during January 2009.

When the analysis is done on the target area using a sensor of Jakarta at a radius of $0.1^{\circ}$, the Standard Deviation value is obtained, $\sigma=58.3$. Furthermore, in the analysis using sensor of Bandung with the same radius, obtained $\sigma=$ 94.3. Thus, the data distribution of both sensors is good and not homogeneous, so the data of the two sensors can generally represent the high lightning randomness or irregularity (chaos) attached to the physical process of lightning formation as described in [23]. Furthermore, the analysis of the target area shows the correlation between both sensors i.e. $r=0.57$. This means, both sensors are good enough to detect the number of lightning strikes on the target area.

Besides that, when the analysis was carried out at a radius of $0.5^{\circ}$ and $1.0^{\circ}$ from the Jakarta and Bandung, the distribution of lightning data showed a very large value with an average of the deviation of each at radius $0.5^{\circ}$ and $1.0^{\circ}$ respectively i.e. $\sigma=698.6$ and $\sigma=1413.2$. Meanwhile, the similarity of pattern between the two sensors in the target area is also smaller with the correlation value at radius $0.5^{\circ}$ and $1.0^{\circ}$ are $r=0.22$ and $r=0.24$ respectively. A description of the correlation between the two sensors in the target area is shown in Fig 3.

Cramer and Cummins (1999) have tested the National Lightning Detection Network (NDLN) for long range detection using the LF spectrum, but the detection efficiency only 10$25 \%$. Thus, it assumed needs placed sensors at least a distance of 5-10 km. Meanwhile, Pessi and Businger (2008) calculated detection efficiency for North and Pacific i.e. 17-23\% and 40-61\% using Pacific Lightning Detection Network (PacNet) with 13-40 km of location detection accuracy. Other significant result of detection efficiency (86-92\%) as in [4] by using Global Lightning Detection (GLD 360) with a distance $30 \mathrm{~km}$.

However, Storm Tracker LD is a standalone sensor which is not integrated with a network. The detection analysis depends on how LD could detect lightning at a certain radius $(\mathrm{km})$. In this case, the calculation is done by using sensor located in Bandung. Assuming the sensor location as the exact value by the number of $100 \%$ efficiency, thus the detection 
efficiency obtained as in Table 2. Furthermore, based on the detection efficiency analysis LD sensor has an optimum range of lightning detection at a distance of $<55 \mathrm{~km}$ from the sensor with the efficiency $73-75 \%$, distance 55 $110 \mathrm{~km}$ from the sensor has efficiency $32-37 \%$ and at a distance of $110-165 \mathrm{~km}$ from the sensor has $8-12 \%$ of efficiency. This calculation is based on the number of strokes on each radius of $0.1^{\circ}, 0.5^{\circ}$ and $1.0^{\circ}$ from the target area (see Fig. 4 for the detail).

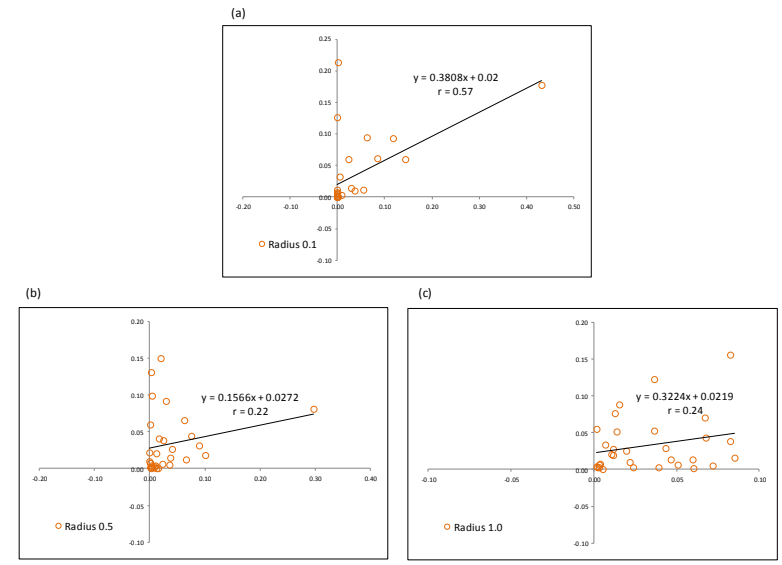

Fig. 3 Scatter plot $\mathrm{CG}$ lightning plotted from Jakarta and Bandung in the target area which is a) Plotted by using $0.1^{\circ}$ radius, b) Plotted by using $0.5^{\circ}$ radius, and c) Plotted by using $1.0^{\circ}$ radius.

TABLE 2. FONT LIGHTNING DETECTION EFFICIENCY BASED ON SENSOR LOCATED IN BANDUNG

\begin{tabular}{|c|c|c|}
\hline $\begin{array}{c}\text { Distance from } \\
\text { sensor }(\mathbf{k m})\end{array}$ & CG Count & $\begin{array}{c}\text { Eficiency } \\
(\boldsymbol{\%})\end{array}$ \\
\hline 0 & 2982 & 100 \\
\hline $0-55$ & $2223-2191$ & $73-75$ \\
\hline $55-110$ & $968-1108$ & $32-37$ \\
\hline $110-165$ & $224-372$ & $8-12$ \\
\hline
\end{tabular}

TABLE 3 COMPARISON OF THE CG LIGHTNING COUNT AT THE TARGET AREA BASED ON SENSORS IN JAKARTA AND BANDUNG

\begin{tabular}{|c|c|c|c|}
\hline \multirow{2}{*}{ No. } & \multirow{2}{*}{ Date } & \multicolumn{2}{c|}{ CG count from } \\
\cline { 3 - 4 } & & Jakarta & Bandung \\
\hline 1 & 24 January 2009 & 50 & 11 \\
\hline 2 & 25 January 2009 & 17 & 54 \\
\hline 3 & 26 January 2009 & 37 & 20 \\
\hline
\end{tabular}

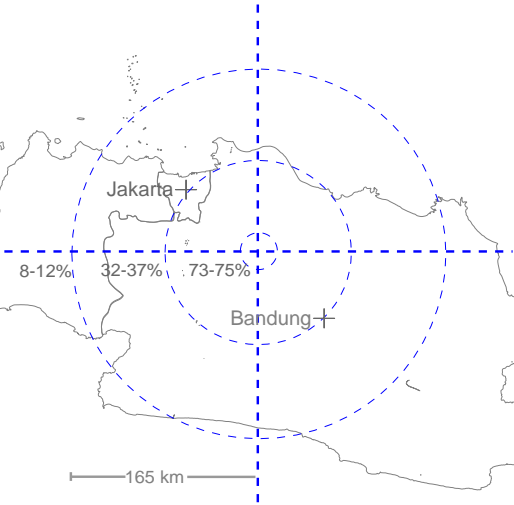

Fig. 4 Efficiency detection of storm tracker lightning detector.

\section{B. The analysis of lightning location error}

For the spatial analysis, a radius of $1.0^{\circ}$ is used from the target area. The objective is to see the pattern and the distribution of CG lightning more widely either through the sensor of Jakarta and Bandung. In details, during January 2009 the lightning data was cumulatively per ten days and then analyzed as shown in Fig. 5.

With a cumulative lightning samples from January 1-10, 2009 (see Fig. 5a and 5b), the lightning distribution between sensors of Jakarta and Bandung shows a much different pattern. Using sensor of Jakarta, the accumulated distribution is to the northwest of Jakarta, far away from the target area. Meanwhile, the lightning distribution using sensor of Bandung is quite well localized in the target area.

However, this is certainly possible because lightning also represents the process of cloud growth, so that the pattern of lightning distribution will follow the spread of clouds around Jakarta. Meanwhile, cumulative lightning data samples from January 11-20, 2009 (see Fig. 5c and 5d), the lightning detection from the sensor of Jakarta remains largely toward the northwest. However, a small fraction of lightning detects around the target area. Furthermore, the lightning distribution detected using the sensor of Bandung also exhibits lightning activity in the target area, although most detect in the southeast of the target area.

Meanwhile, from cumulative lightning data samples of January 21-31, 2009 (see Fig. 5e and 5f), a sensor of Jakarta and Bandung detects many lightning activities around the target area. From sensor of Jakarta, the lightning distribution is well localized around 
Jakarta and partly in the target area. Instead, by using sensor of Bandung, a massive lightning localized in the target area. Finally, from all cumulative data samples as in Figure 5 above, lightning distribution are not all localized in the target area. Only lightning data samples between January 21-31, 2009 (Fig. 5e and 5f) show better distribution patterns than other samples. More detailed, 3 days lightning data from 24-26 January 2009 which has a lot of lightning activities taken for samples analysis.

Hence, a radius of $0.1^{\circ}$ selected with a detection efficiency reaching $75 \%$ and the correlation $r=0.57$ as the results obtained from the previous analysis. The number of lightning by using a radius $0.1^{\circ}$ along 24-26 January 2009 is shown in Table 3. There are three examples for further analysis and describe lightning position if compares between lightning sensor of Jakarta and Bandung.

First, using a sample of January 24, 2009 on a 06.00-07.00 LT, the CG lightning detected by sensor of Jakarta and Bandung, shows the difference of distribution. When detected by lightning sensor of Jakarta, the CG lightning distribution mostly located in the target area.

In contrast, when using the lightning sensor of Bandung, the CG lightning distribution mostly located around at the target area. For further analysis, the CG lightning localized using a radius of $0.1^{\circ}$ around the target area. Mostly CG lightning located in quadrant $3\left(\mathrm{Q}_{3}\right)$ when detected from Jakarta and mostly located in quadrant $4\left(\mathrm{Q}_{4}\right)$ when detected from Bandung (see Fig. 6a). (a)

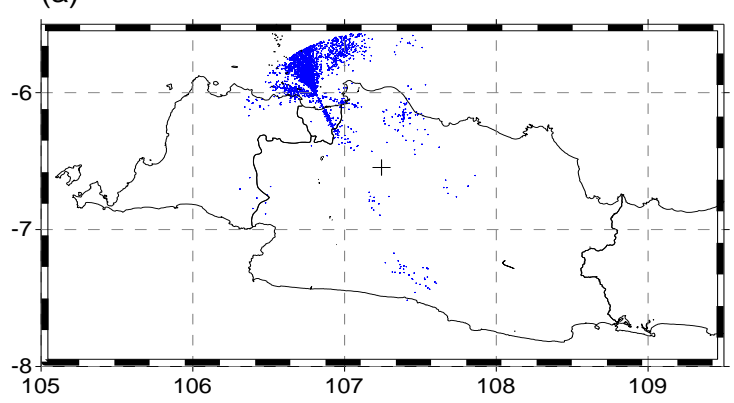

(c)

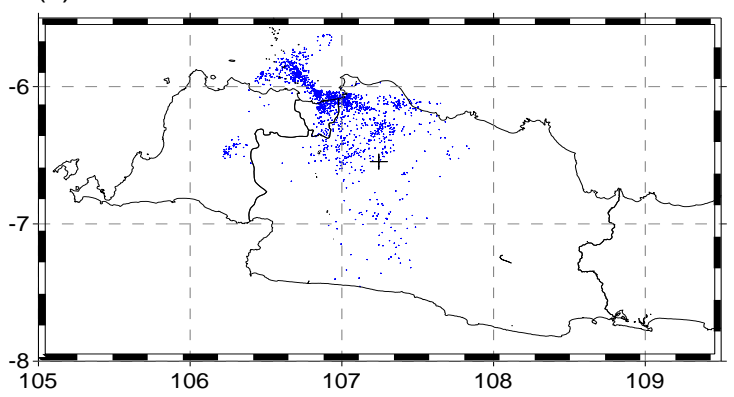

(e)

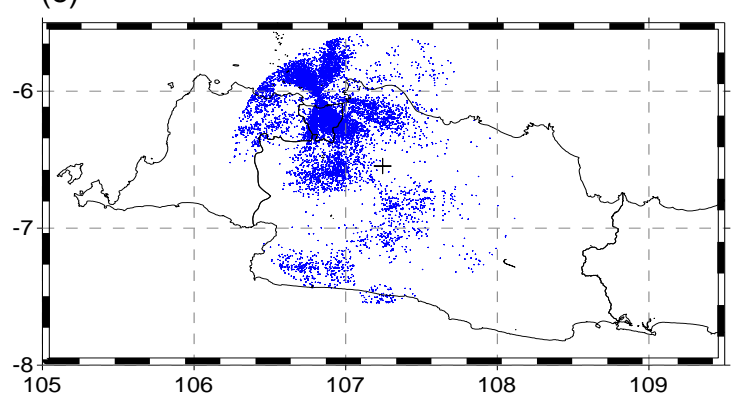

(b)

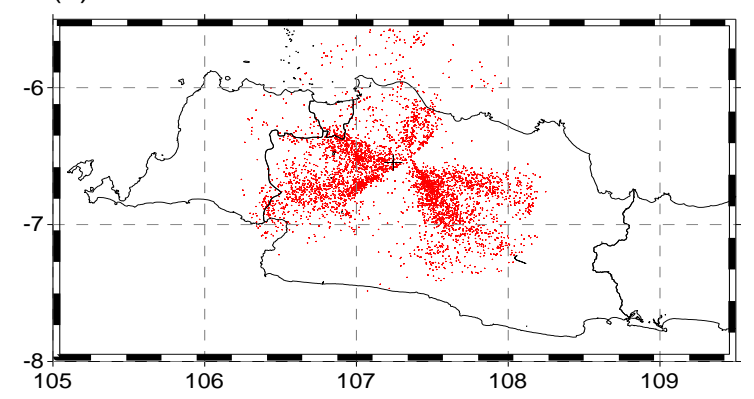

(d)

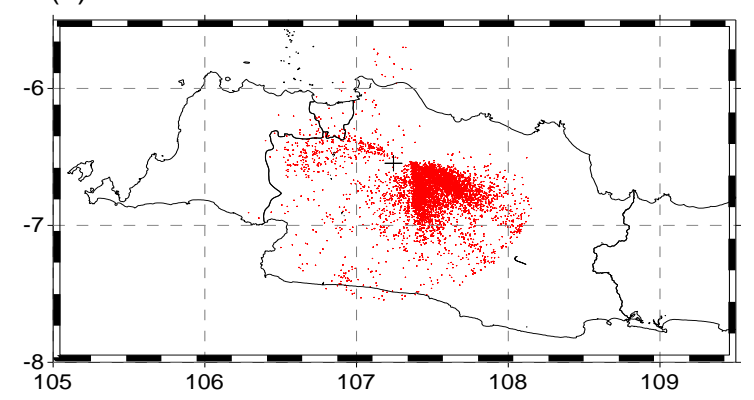

(e)

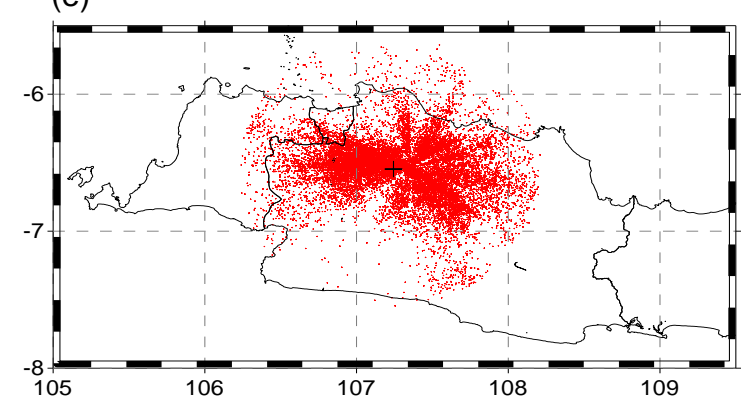

Fig. 5 CG Lightning distribution detected by using lightning sensor of Jakarta (blue) and Bandung (red) which is a) Jakarta from 1-10 January 2009, b) Bandung from 1-10 January 2009, c) Jakarta from 11-20 January 2009, d) Bandung from 11-20 January 2009, e) Jakarta from 21-31 January 2009, and f) Bandung from 21-31 January 2009. 
Second, using a sample of January 25, 2009 on a 14.00-15.00 LT as well as on Figs. 3c and 3d. When detected from Jakarta, the CG lightning distribution mostly located in the middle between target area and Jakarta. Otherwise, when using a lightning sensor from Bandung, the CG lightning distribution mostly located around between target area and Bandung. When localized using a radius of $0.1^{\circ}$ around the target area (see Fig. 6b) mostly CG lightning located at $\mathrm{Q}_{2}$ and then $\mathrm{Q}_{1}$ when detected from Jakarta and located at $\mathrm{Q}_{1}$ and $\mathrm{Q}_{4}$ when detected from Bandung.
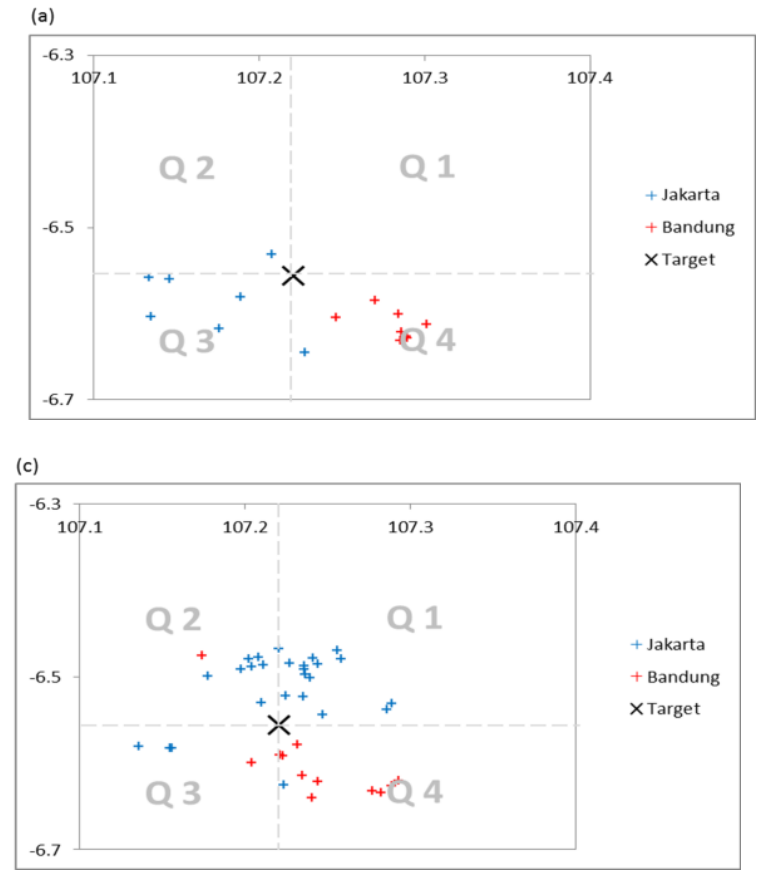

\section{Conclusion}

The objective of this study was to analyze both sensors of Jakarta and Bandung by comparing their distribution in the target area located in the middle between Jakarta and Bandung. This analysis also try to identify detection efficiency both of sensors. Their interpretation are summarized here. The best of detection efficiency of LD located less than $55 \mathrm{~km}$ from the sensor with an efficiency $73-75 \%$. The further away from the sensor, the detection efficiency decreases. Hence, the detection accuracy becomes invalid. Meanwhile, the analysis of lightning location error indicates both sensor has their typical detection itself. From several samples of data analyzed in the target area, only a few samples showed similar patterns of CG lightning distribution.
Third, using a sample of January 26, 2009 on a 13.00-14.00 LT, the CG lightning also indicating difference distribution. Furthermore, detected from the lightning sensor of Jakarta, mostly CG lightning located at the target area. Another result shown when detected from the lightning sensor of Bandung, mostly CG lightning located between target area and Bandung. If localized using radius of $0.1^{\circ}$ around the target area, mostly CG lightning located at $\mathrm{Q}_{2}$ and $\mathrm{Q}_{1}$ when detected from Jakarta and mostly located at $\mathrm{Q}_{4}$ when detected from Bandung (see Fig. 6c).

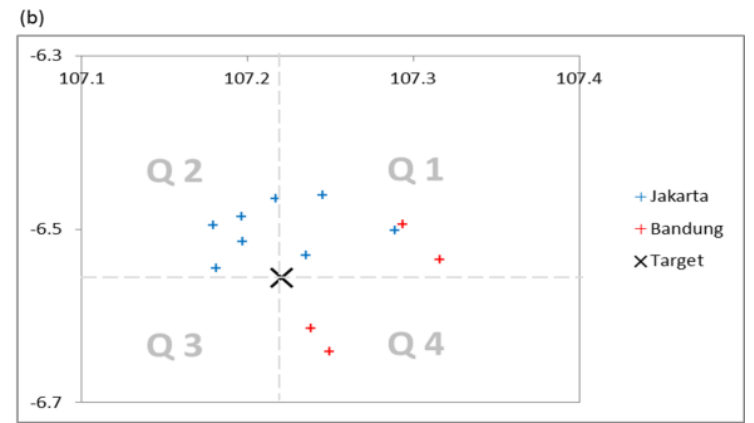

Fig. 6 The distribution of CG lightning detects by using a radius $0.1^{\circ}$ at the target area which is plotted from sensor of Bandung (labeled as "red +") and Jakarta (labeled as "blue + "); $\mathrm{Q}_{1}-\mathrm{Q}_{4}$ indicates Quadrant, with a) Accumulated of CG lightning at 06.00-07.00 LT in January 24, 2009, b) Accumulated of CG lightning at 14.00-15.00 LT in January 25, 2009, and c) Accumulated of CG lightning at 13.00-14.00 LT in January 26, 2009

\section{REFERENCES}

Behnke, S. A., Thomas, R. J., McNutt, S. R., Schneider, D. J., Krehbiel, P. R., Rison, W., and Edens, H. E, "Observations of volcanic lightning during the 2009 eruption of redoubt volcano," J. Volcanol. Geotherm. Res., doi:10.1016/j.jvolgeores.2011.12.010, 2012.

Cramer, J. A. and Cummins, K. L, "Longrange and trans-oceanic lightning detection," Proceedings, 11th International Conference on Atmospheric Electricity, Guntersville, Ala., U.S., NASA Conference Publ. pp. 250-253, 1999.

Cummins, K. L., Martin, M., Demetriades, N. W. S., Pifer, E., Pessi, A., and Businger, S, "Modeling and calibration of vaisala's operational long range lightning detection 
network," International Lightning Detection Conference, Tucson, Arizona, USA, 2008.

Dahoui, M. "Evaluation of The Survey on Ligthning Detection Systems Report on Current Operational Networks," World Meteorological Organization Instruments And Observing Methods Report No. 100. WMO/TD-No. 1542. 2010.

Demetriades, N. W. S., Murphy, M. J., and Cramer, J. A, "Validation of vaisala's global lightning dataset (gld360) over the continental united states,“ International Lightning Detection Conference and International Lightning Meteorology Conference, Tucson, Arizona, USA, 2010.

Demetriades, N. W. S., and Holle, R. L, "Longrange lightning applications for hurricane intensity,"Preprints, Conf. on meteorological Applications of Lightning Data, San Diego, CA, Amer. Meteor. Soc, 2, pp. 1-8. 2005.

Finke, U., and Kreyer, O, "Detect and Locate Lightning Events from Geostationary Satellite Observations," Report Part I, Review of existing lightning location systems, Institute für Meteorologie und Klimatologie, Universität Hannover, 2002.

Holleman, I., Beekhuis, S., Noteboom, H., Evers, L., Haak, H., Falcke, H., and Bähren, L. "Validation of An Operational Lightning Detection System," International Lightning Detection Conference and International Lightning Meteorology Conference, Tucson, Arizona, USA, 2006.

Ibrahim, W. I., and Ghazali, M. R. "Measurements of Electric and Magnetic Fields due to Lightning Strokes Based on Single-station Detection," Universiti Malaysia Pahang, 1-6, 2013.

Johnson, R. L., Janota, D. E., and Hay, J. E, "An operational comparison of lightning warning systems," Journal Appl. Meteor., 21, pp. 703-707, 1982.

Kochtubajda, B., Flannigan, M. D., Gyakum, J. R., Stewart, R. E., Logan, K. A., and Nguyen, $\mathrm{T}$. V, "Lightning and fires in the northwest territories and responses to future climate change," J. Arctic. Vol. 59, No. 2, pp. 211-221, 2006.

Kochtubajda, B., Stewart, R.E., Gyakum, J.R., and Flannigan, M.D, "Summer convection and lightning over the Mackenzie River Basin and their impacts during 1994 and 1995," Atmosphere-Ocean 40:199-220, 2002.

M.A. Uman, "The Lightning Discharge," International Geophysics Series, 39, Academic Press., 2003.

Mather and Harrison, "Electrification of volcanic plumes, "Surv. Geophys. 27, pp. 387432, DOI 10.1007/s10712-006-9007-2, 2006.

Michaelides, S. C., Savvidou, K., Nicolaides, K. A., and Charalambous, M, "In search for relationships between lightning and rainfall with a rectangular grid-box methodology, " $A d v$. Geosci., 20, pp. 51-56, 2009.

MacGorman, D. and Rust, W, "The Electrical Nature of Storms," Oxford University Press, New York. 442, 1998.

Olea, R. A. "Basic statistical concepts and methods for earth," Open-File Report 20081017, Virginia, p. 153, 2008.

Pessi, A. T. and Businger, S, "Development of a long-range lightning detection network for the pacific: construction, calibration, and performance," Journal of Atmospheric and Oceanic Technology. 26, 2008.

Piepgrass, M. V., Krider, E. P., and Moore, C. $\mathrm{B}$, "Lightning and surface rainfall during Florida thunderstorm," J. Geophys. Res., 87(C13), pp. 11193-1120, 1982.

Price, C, "Lightning sensors for observing, tracking and nowcasting severe weather," Sensors 8, pp. 157-170, Department of Geophysics and Planetary Sciences, Tel Aviv University, 69978 Israel, 2008.

Proctor, D. E, "Regions where lightning flashes began,“ Journal Geophys. Res, 96, pp. 5099$5112,1991$.

Purwanto, "Statistika Untuk Penelitian" Penerbit Pustaka Pelajar, Yogyakarta, 282, 2011.

Schumann, U. and Huntrieser, H, "The global lightning-induced nitrogen oxides source," Atmospheric Chemistry and Physics, pp. 38233907, 2007.

Soula, S. and Chauzy, S, "Some aspects of the correlation between lightning and rain activities in thunderstorms, “ Atmos. Res., 56, 355-73, 2001.

Soula, S., Sauvageot, H., Molini'e, G., Mesnard, F., and Chauzy, S, "The CG lightning 
activity of storm causing a flashflood,“ Geophys.Res. Lett., 25, pp. 1181-1184, 1998.

Suszcynsky, D. M., Kirkland, M. W., Jacobson, A. R., Franz, R. C., Knox, S. O., Guillen, J. L. L., and Green, J. L, "FORTE observations of simultaneous VHF and optical emissions from lightning: Basic phenomenology,“ J. Geophys. Res., $\quad 105, \quad$ pp. 2191-2202, doi:10.1029/1999JD900993, 2000.

Thomas, R. J., Krehbiel, P. R., Rison, W., Hamlin, T., Boccippio, D. J., Goodman, S. J., and Christian, H. J, "Comparison of groundbased 3-dimensional lightning mapping observations with satellite-based LIS observations in Oklahoma," Geophys. Res. Lett., 27, pp. 1703-1706, doi:10.1029/1999GL010845, 2000.

Squires. K. and S. Businger, "The morphology of eyewall lightning outbreaks in two category five hurricanes," Mon. Wea. Rev., in press., 2008.

Septiadi, D., Widada, S. and Prayitno, S. A, "The Use of Lightning Data for Convective Rainfall Estimation," Scientific Journal of PPIUKM, Vol.3 No. 4, pp. 166-171, 2016.

Septiadi, D. and Safwan, H. "Karakteristik Petir Terkait Curah Hujan Lebat Di Wilayah Bandung, Jawa Barat," Jurnal Meteorologi dan Geofisika, ISSN 1411-3082, Vol. 12 No.2, 163170, 2011.

Septiadi, D., Safwan, H. and Bayong, T.H.K. "Karakteristik Petir Dari Awan ke Bumi dan Hubungannya dengan Curah Hujan," Jurnal Sains Dirgantara, ISSN 1412-808X, Vol. 8 No.2, 2011.

Septiadi, D. and Bayong,T.H.K. "Variabilitas Musiman Cloud Ground Lightning dan Kaitannya dengan Pola Hujan di Wilayah Jawa
(Sudi Kasus Bandung dan Semarang)," Jurnal Bumi Lestari, Vol. 11 No. 1, pp. 1 - 8, 2011.

Septiadi, D., Safwan, H. and Bayong, T.H.K. "The Simulation of Weather Early Warning System Using Lightning Data in Anticipating of Extreme Weather Event in Bandung," International Proceedings ISBN : 979-9783456-68-5 at 5th Kentingan Physics and Its Applications, Environmentally Friendly Technology and Disaster, pp. 235-238, 2010.

Tinmaker, M. I. R and Ali, K. "Association of lightning with rainfall and surface air temperature over a tropical inland station, Pune, India," 30th International Conference on Lightning Protection - ICLP, 747, 1-4, 2010. 